\title{
The Content and Purposes of Talk that Accompanies Oral Reading Events: Insights from a Mother-Daughter Case Study
}

\author{
BOBBIE KABUTO \\ Queens College, City University of New York
}

\begin{abstract}
This article investigates the substance and possible purposes of talk that accompanies oral reading events within a mother-daughter case study. The findings presented in this paper are from a case study that was part of a larger Family Retrospective Miscue Analysis study that assisted parents in becoming strategic partners who build on the strengths of their children when reading with them. This article presents the functions of talk that accompany oral readings, the insights gained about reading as a meaning-construction process, and how parents can benefit from listening to their children's talk during oral reading sessions.
\end{abstract}

Becky said that she liked to read but did not see herself as a good reader. When asked why she did not believe she was a good reader, she replied, "I don't really want to be a reader." A little struck by this comment, Becky was asked whether there were things that she already read. She replied that she read books such as House for Hermit Crab, stop signs, red lights, and restaurant signs. After hearing the things that Becky listed, she was asked if she would like to be a better reader. Becky countered with "Why?"

The above vignette was part of a reading interview conducted with Becky, a 9year-old struggling reader who, along with her mother Nancy, participated in a research study that sought to investigate the family dynamics between struggling readers and their parents and to explore how their parents worked with these readers in the home setting.

This article seeks to explore the nature of the talk that spontaneously evolved out of Becky's oral reading during 10 family reading sessions with Becky and her mother Nancy. Talk, as seen in this article, is viewed as a window into Becky's thinking when she is reading and as a social means for knowledge construction. This article addresses the following questions that evolved out of the case study:

- What functions does talk serve for Becky as she is orally reading?

- What insights can other participants gain by studying how Becky problemsolves with texts when listening to her self-verbalizing talk? 
- $\quad$ How does talk provide an exploratory space for parents to investigate and gain a better understanding of the reading process with their children?

The significance of these questions lies in the argument that individuals working with readers, both parents and teachers, need to become informed listeners who know what they are listening to when readers engage in talk while reading; however, attempts to listen effectively are successful only when such individuals are trained to listen and respond to those around them (Wolf, Crosson, \& Resnick, 2004). There is very little published research on how to assist parents in becoming strategic reading partners with their children. Parents are in a particularly difficult situation because most parents are not "trained" like educators to listen to readers. For this reason, this article aims at exploring what becoming a strategic reading partner entails through examining the content, purposes, and talk that accompany oral reading events.

\section{Talk and Reading Processes}

Built on a Vygotskian perspective on how talk mediates and contributes to knowledge (Vygotsky, 1986), the two types of talk that build a foundation for the research presented in this article are think alouds, or self-verbalization style talk and exploratory talk. The literature on think alouds defines this type of talk as both research and instructional techniques that allow readers to verbalize their thinking and ideas as they read (Kucan \& Beck, 1997). Used within methodological frameworks, think alouds are seen as a type of introspection that generates verbal reports that highlight what readers are thinking as they are reading (Kucan \& Beck, 1997). By engaging in think alouds, readers stop their reading to try to make sense of what they are reading, to explore ideas or problems, or to find solutions to problems. By studying think alouds, researchers have enhanced their understanding about reading as a problem-solving process by investigating the kinds of problems readers encounter when they read and the strategies they use in monitoring comprehension (e.g., Crain-Thoreson, Lippman, \& McClendonMagnuson, 1997; Kucan \& Beck, 1997; Oster, 2001).

The literature further describes the types of strategies or the means readers employ when entering, monitoring, and engaging in reading and developing comprehension (e.g., Duke \& Pearson, 2002; Oster, 2001; Wolf et al., 2004). Through the use of think alouds, research has illuminated specific strategies, such as setting purposes before reading, developing questions, solving unclear ideas, and summarizing ideas as they read (e.g., Duke \& Pearson, 2002; Kucan \& Beck, 1997; Staskowski \& Creaghead, 2001). Most notable is the argument that think-alouds allow readers to demonstrate their strengths as they verbalize their thinking and, thus, to illustrate how they envision and develop personal connections to stories. Furthermore, through selfverbalization, readers develop their metacognitive awareness (e.g., Israel \& Massey, 2005; Kymes, 2005). Oster (2001) reports, "This metacognitive awareness (being able to think about one's own thinking) is a crucial component of learning, because it enables learners to assess their level of comprehension and adjust their strategies for greater success" (p. 64). The investigation of think alouds allows researchers to gauge readers' metacognitive awareness, which, in turn, highlights their strengths as readers (Oster, 2001). 
Think alouds are spaces for exploratory talk or a type of "think aloud talk" that evolves out of problem-solving contexts (Barnes, 1993). According to Barnes (1993), exploratory talk is the result of active learning developed within a constructivist framework, as participants can engage in each other's ideas with the goal of developing alternative solutions and reaching agreements. While think aloud talk is a selfverbalization, exploratory talk is shared with other participants, who exchange, challenge, or support ideas. The literature on exploratory talk defines it as a means for knowledge construction, as old ideas are reformed into new ones (Mercer, 2000). Exploratory talk, thus, has unique characteristics that make it different from other types of talk.

Mercer (2000) uses the term "interthinking" to describe the ways in which talk allows for collective thinking and, building on Mercer's work, Pantaleo (2007) argues that individuals learn by talking and through talking. This idea of interthinking, or the joint construction of knowledge through the medium of language (Mercer, 2000), is crucial in establishing the usefulness and benefits of assisting parents in understanding their children's reading behaviors. Parents and their children are able to explore and learn about not only about the reading process, but also about each other by engaging in and listening to talk accompanying oral reading events. Hanks (as cited in Lave \& Wenger, 1991) argues, "Learning is, as it were, distributed among coparticipants, not a one-person act" (p. 15), and as such, through the use of talk as a social and cognitive tool, parents and children together are able to engage in learning experiences around reading with the hopes of parents viewing their children's strengths as readers.

\section{A Look at Reading through the Lens of Talk}

The findings presented in this paper are from a case study that was part of a larger Family Retrospective Miscue Analysis (Family RMA; Kabuto, 2009) study that assisted parents in becoming strategic partners who build on the strengths of their children when reading with them. Families who participated in the Family RMA study engaged in 10 one-hour weekly sessions. One of the goals of the larger study was to model the ways in which parents can react and interact with their children as they read. In order to do so, the study sought to aid parents in (a) becoming informed listeners, (b) knowing when and how to intervene during the reading, and (c) becoming knowledgeable about ways of talking with and about reading with their children (Kabuto, 2009).

A large corpus of longitudinal data was generated by this study. The following discourse analysis procedure was coalesced with other data analyses, in particular miscue analyses, used to analyze the oral readings and retellings, and interpretative coding/categorizing of field observations and interview data. Observations, parent interviews, child interviews, oral readings from parents and their children, retrospective discussions of the oral readings, and observational and reflective notes from the researcher were collected throughout the 10 sessions and are described in further detail below.

\section{Observations}

\section{Research Design}

Parents and their children were observed interacting with print in the home. Each visit included interviews regarding daily home literacy practices and school activities. 


\section{Parent Interviews}

At the beginning and end of the study, parents were interviewed using the Burke Reading Inventory (Goodman, Watson, \& Burke, 2005) about their definition of reading, how they learned to read, what they saw as the important aspects of reading, and how they felt about themselves as readers. In addition, parents were interviewed about their perceptions of their children's reading abilities, their children's progress in school, how they saw the school's role in providing services to support their children's reading and writing, and their goals for their children's literacy progress.

\section{Child Interviews}

Children were interviewed at the beginning and the end of the study by means of the Burke Reading Interview. The reading interview contained the same questions as those given to their parents. They were also interviewed regarding daily home literacy practices, school activities, and the homework and work they did in school in reading and writing.

\section{Observational and Reflective Notes from Participant Observation}

This study involved participant-observation, which is an ethnographic research design in which the researcher becomes actively involved in the research process (Agar, 1996). As the researcher, it is important to acknowledge my role because one of the goals of the study is for parents to observe effective interactive reading behaviors between proficient and struggling readers. Furthermore, Becky was not immune to my presence, which co-constructed the reading format during the research process. While talk can serve a function for the speaker, as Vygotsky (1986) noted, talk is also a social tool through which more experienced members engage with the learning of the novice participant. Taking this theoretical stance towards learning and valuing the importance of engaging Becky within reading formats, I participated in the talk when Becky wanted to bring me into the conversation. During these times, I paid close attention to the type of talk that I was using with the goal of continuing Becky's exploration of reading so that she could discover answers on her own, rather than relying on me to give them to her.

Consequently, documenting how my role and ideologies co-construct the research is of critical importance. Within the ethnographic tradition, written observational notes were taken at every session, which were also audio-taped and later transcribed. The observational notes provided contextual information and captured spontaneous dialogue that evolved out of the sessions. After the sessions were transcribed, the transcription and observational notes were examined together in order to write reflective notes that discussed the researcher's role in the research and overall themes that evolved out of each session.

\section{Oral Readings and Miscue Analysis}

Both parents and children participated in oral readings. After the oral readings were completed, story retellings were elicited. Parents were asked to read a variety of materials that were self-selected, selected by their children, or selected by me. Some of the types of reading materials ranged from newspapers to popular magazines, such as Time, to children's books. By the end of the 10 sessions, parents conducted two oral 
readings (see Table 1 for an outline of the Family RMA sessions). Children either read from self-selected texts or from books at their reading levels as determined by the Qualitative Reading Inventory-4 (QRI-4; Leslie \& Caldwell, 2006). After the oral readings were conducted, they were analyzed and coded using standard miscue procedures (Goodman, et al., 2005). Children participated in a total of three oral readings (see Table 1).

Table 1

Outline of Oral Readings and Reflective Discussions within the Family RMA Study

\begin{tabular}{ll}
\hline Session 1 & Parent and child reading interviews \\
\hline Session 2 & Conduct oral reading with the child \\
\hline Session 3 & $\begin{array}{l}\text { Conduct retrospective discussions on the child's } \\
\text { oral reading } \\
\text { Conduct oral reading with the parent }\end{array}$ \\
\hline Session 4 & $\begin{array}{l}\text { Conduct retrospective discussions on the } \\
\text { parent's oral reading }\end{array}$ \\
\hline Session 5 & Conduct oral reading with the child \\
\hline Session 6 & $\begin{array}{l}\text { Conduct retrospective discussions on the child's } \\
\text { oral reading } \\
\text { Conduct oral reading with the parent }\end{array}$ \\
\hline Session 7 & $\begin{array}{l}\text { Conduct retrospective discussions on the } \\
\text { parent's oral reading }\end{array}$ \\
\hline Session 8 & Conduct oral reading with the child \\
\hline Session 9 & $\begin{array}{l}\text { Conduct retrospective discussions on the child's } \\
\text { oral reading }\end{array}$ \\
\hline Session 10 & Parent and child closing reading interview \\
\hline
\end{tabular}

Retrospective Miscue Analysis

Retrospective miscues analyses (RMA) are retrospective discussions about the readers' oral readings and were conducted with both parents and children (Goodman \& Marek, 1996). This study incorporated Family RMA discussions (Kabuto, 2009), during which all family members were shown their pre-selected oral reading miscue codings. A miscue is an observed response that differs from the written text (Goodman, 1996). Examples of questions that are used to guide RMA discussions are as follows: What were you thinking? Did your oral reading make sense? Did your produced reading look or sound like the written text? What did you learn about reading? What did you learn about yourself as a reader? It is important to note that only the reader's high quality miscues were introduced during RMA discussions. High quality miscues are miscues that do not change the meaning of the text (e.g., substituting home for house). At the conclusion of the oral reading sessions, there were two RMA sessions based on the parents' oral readings and three RMA sessions based on their children's readings (see Table 1). 
All the sessions were audio-taped and transcribed. The transcriptions were combined with miscue analysis data, observational data, and reflective notes.

Nancy and Becky: A Case Study

During the screening interview, Nancy described Becky as a "sweet, easy going" child. Nancy explained that, at the time of the study, Becky was classified in school as having a learning disability. Becky was in the third grade but had been held back in kindergarten. Nancy volunteered for the study because she wanted to know how to help Becky with reading.

Becky was labeled as a struggling reader through different lenses. Becky's mother supported the school's label of Becky as a struggling reader by describing her as "barely reading." In addition, Becky did not identify herself as a reader when, in fact, she described how she was actively engaged in different types of reading, as the opening vignette illustrates.

Table 2 outlines the books that Becky read for her oral readings. Becky read three stories that were selected based on her QRI-4 results (Leslie \& Caldwell, 2006), which placed her reading at level 1 . Books were chosen based not only on their level, but also on the amount of repetitious language and picture support they provided to Becky. After Becky read, Becky, Nancy, and I discussed Becky's oral reading through the RMA procedures presented above in order to gain insights into what Becky was thinking as she was reading. In order to begin the conversation, I showed Becky a high quality miscue; for example, Becky read quack instead of scat in the following sentence, "And the duck said, 'Scat.' But the bee just sat" (Lewison, 1992, p. 4). High quality miscues are considered "good" miscues because they do not change the meaning or the grammar of the sentence, and consequently make sense within the sentence. These types of miscues were important to discuss with both Becky and Nancy because the discussion allowed them to differentiate between "good" miscues that did not change the meaning of the story and "bad" miscues that disrupted the meaning and/or grammar of the sentence. The differentiation between miscues is important in assisting parents, like Nancy, in determining when they should intervene in the reading. In other words, part of the process of working with Nancy and Becky was helping Nancy be a strategic partner by addressing miscues that disrupted the meaning and/or grammar of the sentence. 
Table 2

Outline of Books and the Number of Oral Reading-to-Talk Shifts and Talk-to-Oral Reading Shifts

\begin{tabular}{|c|c|c|c|c|}
\hline Books & Synopsis & $\begin{array}{l}\text { Number of } \\
\text { Oral-Talk } \\
\text { Shifts } \\
\end{array}$ & $\begin{array}{l}\text { Number of } \\
\text { Talk-Oral } \\
\text { Shifts }\end{array}$ & Total Shifts \\
\hline $\begin{array}{l}\text { It Looked Like } \\
\text { Spilt Milk by } \\
\text { Charles Shaw } \\
(1947)\end{array}$ & $\begin{array}{l}\text { A repetitive book } \\
\text { about how clouds } \\
\text { can make different } \\
\text { shapes in the sky. }\end{array}$ & 7 & 7 & 14 \\
\hline $\begin{array}{l}\text { Buzz Said the } \\
\text { Bee by Wendy } \\
\text { Lewison (1992) }\end{array}$ & $\begin{array}{l}\text { A predictable, } \\
\text { rhyming book about } \\
\text { animals sitting on } \\
\text { top of each other } \\
\text { until they collapse. }\end{array}$ & 15 & 15 & 30 \\
\hline $\begin{array}{l}\text { Going to School } \\
\text { by R. Smith } \\
(1996)\end{array}$ & $\begin{array}{l}\text { A repetitive book } \\
\text { about a little girl } \\
\text { who is going to } \\
\text { school by herself } \\
\text { because her brother } \\
\text { is sick. }\end{array}$ & 18 & 18 & 36 \\
\hline & & 40 & 40 & 80 \\
\hline
\end{tabular}

The three oral readings alone resulted in 1 hour and 45 minutes of transcribed data. In spite of the fact that Becky read from short, predictable books with little text and strong picture support, her oral readings were drawn out because she always engaged in accompanying talk. This behavior was unique to Becky and Nancy's case study within the larger study. In addition, observational data of Becky and Nancy's interactions around reading showed that when Becky stopped the reading to ask a question or talk her way through her reading, Nancy either directly answered the question or told Becky to "just concentrate." Frustration from both mother and daughter manifested itself in their reading interactions. Nancy explained this frustration by reasoning that she did not know how to help Becky and that she could not relate to Becky's struggles. These observations warranted further investigation into the role that talk was serving for Becky. Investigating the role of talk in conjunction with Becky's miscues allows both Nancy and me to understand Becky's reading behaviors and to listen and react better to Becky's talk with the goal of co-constructing more effective social interactions with Becky around reading.

\section{Data Analysis}

In the following, I present the discourse analysis procedures that were used to analyze the oral reading events. The subsequent oral reading events and analysis only 
include interactions between Becky and me. Nancy was an observer while I collected oral reading data on Becky and reflected on Becky's oral readings through the RMA procedures, which informed the findings that are presented.

This study followed an inductive approach in which the codes evolved out of the data (Rogers, 2004; Thomas, 2003). Becky's three oral readings were transcribed and the transcriptions were broken down into utterances that were coded for (a) the oral reading of the text and (b) accompanying talk. After the utterances were coded for the oral reading and talk, oral reading-to-talk and talk-to-oral reading shifts were marked. There were 80 shifts within the 1 hour and 45 minutes of oral readings. Shifts were analyzed separately to determine the reader's purpose in shifting the talk and the relationships between the shifts.

\section{Oral Reading-to-Talk Shifts}

Table 3 outlines the codes used in the oral reading-to-talk shifts. Table 2 shows that Becky made 18 oral reading-to-talk shifts, which is the highest number of shifts, when reading Going to School (Smith, 1996) and the lowest number (7 shifts) when reading It Looked like Spilt Milk (Shaw, 1947). Becky made 15 oral reading-to-talk shifts in Buzz Said the Bee (Lewison, 1992). For the individual codes, Becky made oral reading-to-talk shifts to disconfirm her predictions $47.5 \%$ of the time while she switched to confirm her predictions $12.5 \%$ of the time (see Table 4). Furthermore, $27.5 \%$ of Becky's shifts in this category were used to explore written language. Based on Becky's shifts, the fewest occurrences accompanied Becky's sampling pictures (5\%), predicting upcoming text or plot $(5 \%)$, and terminating her reading $(2.5 \%)$.

Table 3

Codes to Identify Oral Reading-to-Talk Shifts

Type of Shift Explanation Example

Disconfirming This code tagged shifts in which predictions Becky did not believe that her produced response to the sentence was acceptable. There were two particular behaviors that identified this shift. One was Becky's open statement that her response was not correct. The second type of response was Becky's asking for help.

Exploring Within these shifts, Becky seemed written language to be exploring orthographic and phonemic principles related to
Becky read the phrase in Buzz Said the Bee (Lewison, 1992) "And the duck said, 'Scat", (p. 5) as "And the duck said, "Help." Becky shifted the talk to say, "No. It's not help."

When reading Going to School (Smith, 1996), Becky had a difficult time with the word 
written language. A common theme within this code was for Becky to move outside of the oral reading to sound out words or to ask for phonics rules.

Sampling pictures

Confirming predictions

Predicting

Terminating
Becky moved out of oral reading to sample and comment about the pictures.
This code was characterized by Becky's comments on whether her predictions made sense.

Predicting codes were used to mark points at which Becky verbalized what she thought would happen next. hurry in the sentence "Hurry, or you'll miss the bus" (p. 3). When Becky came upon the word hurry, she said, "/H/ /ur/. What does $y$ say?"

Becky had difficulty with the phrase Great Horned Owl. Before Becky substituted the word goat for the phrase Great Horned Owl, she looked at the picture and commented, "That looks like an owl or a goat."

After Becky disconfirmed her prediction concerning the word scat in Buzz Said the Bee (Lewison, 1992), Becky eventually produced the expected response. After reading, "And the duck said, 'Scat," Becky replied, "That goes," meaning that her second response made sense within the sentence.

When reading Going to School (Smith, 1996), Becky came across the repetitious sentence "Sorry, Kitty, I can't play with you now" (p. 5) for the first time. Before she began the sentence, she commented, "She is going to say sorry."

Toward the end of Going to School (Smith, 1996), Becky read the sentence "Hello, Miss Sharp. Thanks for waiting" (p. 16) as "Hello, Miss Sharp. Thank you for ...." Having trouble with the word waiting, Becky decided that she wanted to finish the reading and said, "Done." 
Table 4

Codes, Numbers, and Percentages of Oral Reading-to-Talk Shifts

\begin{tabular}{|c|c|c|c|c|c|}
\hline \multirow[t]{6}{*}{ Type of Shift } & It Looked & Buzz & \multirow{6}{*}{$\begin{array}{l}\text { Going to } \\
\text { School }\end{array}$} & \multirow{3}{*}{$\begin{array}{l}\text { Total } \\
\text { Number of } \\
\text { Shifts }\end{array}$} & \multirow{2}{*}{$\begin{array}{l}\text { Total } \\
\text { Percentages }\end{array}$} \\
\hline & Like Spilt & Said the & & & \\
\hline & Milk & & & & of Shifts \\
\hline & & & & Across All & Across All \\
\hline & & & & Three & Three \\
\hline & & & & Books & Books \\
\hline $\begin{array}{l}\text { Disconfirming } \\
\text { predictions }\end{array}$ & 4 & 8 & 7 & 19 & $47.5 \%$ \\
\hline $\begin{array}{l}\text { Exploring written } \\
\text { language }\end{array}$ & 2 & 3 & 6 & 11 & $27.5 \%$ \\
\hline $\begin{array}{l}\text { Sampling } \\
\text { pictures }\end{array}$ & 1 & - & 1 & 2 & $5 \%$ \\
\hline $\begin{array}{l}\text { Confirming } \\
\text { predictions }\end{array}$ & -- & 4 & 1 & 5 & $12.5 \%$ \\
\hline Predicting & -- & - & 2 & 2 & $5 \%$ \\
\hline Terminating & -- & -- & 1 & 1 & $2.5 \%$ \\
\hline Totals & 7 & 15 & 18 & 40 & $100 \%$ \\
\hline
\end{tabular}

\section{Talk-to-Oral Reading Shifts}

The talk-to-oral reading shifts were characterized by Becky's return to reading the story aloud. Of particular interest in these shifts was the degree to which Becky made decisions about incorporating the content of her talk into the oral reading. These shifts were coded with either a yes, indicating the content of the talk was incorporated, or no, indicating the content of the talk was not incorporated. For example, in the following dialogue, Becky attempted to read the sentence "So the hen danced a jig and sat on a pig" (Lewison, 1992, p. 10-11).

"Dancing on a . . .," Becky read. “/j//i//g/. Jig," Becky sounded out the word jig and then read the word.

"That makes sense," Becky confirmed her prediction and continued to read the sentence "And sat on a pig."

Becky made two talk-to-oral reading shifts. The first shift occurred after Becky sounded out the word jig and then read it in the text. Because Becky incorporated the sounded out word in her reading and read it conventionally, this shift was coded with a 
yes, since Becky incorporated the content of her talk within the oral reading. The second talk-to-oral reading shift occurred after she read the word jig and commented that her prediction made sense. Becky confirmed her prediction and continued to read the sentence. Again, this shift was coded as a yes because of the integration of the talk in the oral reading.

An example of not including the content of the talk occurred in the following dialogue that accompanied Becky's attempt at the sentence "Hurry, or you'll miss the bus" (Smith, 1996, p. 3).

“/H/ /ur/. What does $y$ make?" Becky asked as she tried to sound out the word.

"Why don't you try?" I replied.

"You're /m/ /i/," Becky attempted and read, "the bus."

In this example, Becky again made two talk-to-oral reading shifts during which she did not include the content of the talk. In the first shift, Becky tried to sound out the word hurry and asked what sound the $y$ has in the word hurry. When I suggested that she make an attempt, Becky ignored both her attempt at the word and my suggestion by omitting the word. Becky read you'll as you're and wanted to sound out the word miss from which she attempted the first two sounds. In this second talk-to-oral reading shift, Becky did not complete the word and produced two phonemic sounds in the word miss, eventually omitting the word to complete the rest of the sentence.

Becky incorporated the content of her talk into her oral reading $80 \%$ of the time. This percentage suggests that Becky made positive decisions to include the content of her talk as she responded to her understanding of the story. The two examples, which are indicative of the larger data set, show that when Becky incorporated the content of her talk, she was actively addressing the reading activity, problem solving the letter-sound relationships within written language, and confirming/disconfirming her understanding.

\section{Participant-Observer Talk}

Because the sessions were co-constructed between Becky and me as the researcher and participant-observer, my talk assisted in guiding and developing the thinking that occurred. In addition, the nature of the sessions allowed for Nancy to observe my interactions with Becky around reading. It is important to analyze what Nancy was observing as the reading formats were being co-constructed between Becky and me. Following an ethnographic lens of participant-observation, I call this talk Participant-Observer Talk.

The participant-observer talk was coded for its content and purpose (see Table 5). The codes that were used were based on the work of Mercer (2000) who outlined five talk techniques used in classrooms in developing students' conceptual understandings. The participant utterances were coded for each of these techniques. Once the utterances were coded, the codes were outlined. Out of the three reading sessions with Becky, elicitations were the technique that appeared the most at $70.6 \%$. After elicitations, there were a roughly similar number of repetitions at $11.8 \%$ and reformulations at $15.7 \%$. Exhortations occurred $2 \%$ of the time, while recaps did not occur (see Table 6 ). 
Table 5

Codes for Participant-Observer Talk

\begin{tabular}{|c|c|c|}
\hline Code & Definition & Example \\
\hline Recaps & $\begin{array}{l}\text { Recaps are brief discussions of what } \\
\text { has already previously happened. } \\
\text { They serve the purpose of reminding } \\
\text { students of what has already been done } \\
\text { in order to set up the new activity. }\end{array}$ & Not present. \\
\hline Elicitations & $\begin{array}{l}\text { Elicitations are ways of getting } \\
\text { information from the student. As } \\
\text { Mercer (2000) notes, elicitations are } \\
\text { usually questions. }\end{array}$ & $\begin{array}{l}\text { When Becky was reading the } \\
\text { sentence, "Sometimes it looks like } \\
\text { Great Horned Owl" (Shaw, 1947, p. } \\
\text { 19), she asked, "What does that } \\
\text { word say?" referring to the phrase } \\
\text { Great Horned Owl. I countered } \\
\text { with the question, "What do you } \\
\text { think it might say?" }\end{array}$ \\
\hline Repetitions & $\begin{array}{l}\text { Repetitions are when students' } \\
\text { responses are repeated in order to } \\
\text { affirm or disconfirm their response. }\end{array}$ & $\begin{array}{l}\text { When reading Buzz Said the Bee, } \\
\text { Becky said, "No. It's not help," } \\
\text { referring to the word scat in the } \\
\text { sentence, "And the duck said, } \\
\text { 'Scat,' but the bee just sat" } \\
\text { (Lewison, 1992, p. 4). I repeated } \\
\text { Becky's response as a way to affirm } \\
\text { it by saying, "No. It's not help." }\end{array}$ \\
\hline Reformulations & $\begin{array}{l}\text { Reformulations are responses that are } \\
\text { paraphrased responses. Reformulations } \\
\text { present the same idea in a different } \\
\text { form. }\end{array}$ & $\begin{array}{l}\text { Becky was having a difficult time } \\
\text { with the word hurry in the sentence, } \\
\text { "'Hurry, or you'll miss the bus" } \\
\text { (Smith, 1996, p. 3). Becky said, "I } \\
\text { don't know this word." I replied, } \\
\text { "You are stuck on that word" } \\
\text { pointing to hurry. }\end{array}$ \\
\hline Exhortations & $\begin{array}{l}\text { Exhortations are when students are } \\
\text { asked to recall previous events with the } \\
\text { goal of relating their current } \\
\text { experience with previous ones. }\end{array}$ & $\begin{array}{l}\text { Becky was having a difficult time } \\
\text { pronouncing the word cluck in the } \\
\text { sentence, "Cluck, said the hen" } \\
\text { (Lewison, 1992, p. 7), and asked me } \\
\text { to give her the word. I responded to } \\
\text { her request by stating, "Do you } \\
\text { remember what happened last time? } \\
\text { As you got into the book you } \\
\text { figured out the word (you were } \\
\text { having trouble with) and you } \\
\text { decided to go all the way back to } \\
\text { reread the story. Maybe that will }\end{array}$ \\
\hline
\end{tabular}


Table 6

Codes, Numbers, and Percentages for Participant-Observer Talk

\begin{tabular}{|c|c|c|c|c|c|}
\hline $\begin{array}{lr}\text { Occurrence } & \text { of } \\
\text { Codes } & \text { for } \\
\text { Participant- } & \\
\text { Related Talk } & \end{array}$ & $\begin{array}{l}\text { It Looked } \\
\text { Like Spilt } \\
\text { Milk }\end{array}$ & $\begin{array}{l}\text { Buzz } \\
\text { Said the } \\
\text { Bee }\end{array}$ & $\begin{array}{ll}\text { Going to } \\
\text { School }\end{array}$ & $\begin{array}{l}\text { Total } \\
\text { Participant- } \\
\text { Related } \\
\text { Codes }\end{array}$ & $\begin{array}{l}\text { Percentages } \\
\text { of } \\
\text { Participant- } \\
\text { Related } \\
\text { Codes }\end{array}$ \\
\hline Recaps & 0 & 0 & 0 & 0 & $0 \%$ \\
\hline Elicitations & 10 & 14 & 12 & 36 & $70.6 \%$ \\
\hline Repetitions & 0 & 4 & 2 & 6 & $11.8 \%$ \\
\hline Reformulations & 3 & 1 & 4 & 8 & $15.7 \%$ \\
\hline Exhortations & 0 & 1 & 0 & 1 & $2 \%$ \\
\hline Totals & 13 & 20 & 18 & 51 & $100.1 \%$ \\
\hline
\end{tabular}

Functions of Talk

Talk provided Becky with a way to shift from reading aloud to engaging in a discussion about some aspect of the written text within the story. In other words, when Becky came across difficult areas, think alouds and exploratory talk were a means for her to pause, question, reconsider, and redirect her reading. The following dialogue illustrates how Becky used talk to disconfirm predictions about how she thought the sentence should read. Here, Becky is attempting the sentence "Sometime it looked like an angel" (Shaw, 1947, p. 28).

"Sometime it looks like a bird," Becky read. "I don't know that word," Becky said pointing to the word angel.

"What do you think it could be?" I asked.

"A butterfly," Becky replied as she looked at the picture.

"Okay."

"But it doesn't have a $b$," Becky said while looking at the first letter of angel.

"No, it doesn't," I agreed.

"But what can it be?" Becky continued.

"Can you think of another word that might start with an $a$ ?"

"Ant," Becky said. "Maybe it's a bug." 
“It looks like a bug. It wasn’t a bug. Bug. A ladybug," Becky read.

In this dialogue, Becky substituted the word bird for angel probably because the abstract picture of white on a blue background looked like a bird. Becky shifted the talk to disconfirm her response because she knew that bird did not start with the letter $a$. Within this shift, the talk lasted nine turns between Becky and me before Becky shifted back into the oral reading. Within the nine turns, Becky first disconfirmed her prediction and attempted to make another prediction based on some of the letter-sound relationships that were present in the word angel. The attempt caused Becky to suggest that the word could be ant; however, the fact that the picture did not look like an ant caused Becky to make another prediction based on the picture. Because Becky did not want to return to butterfly, she said "bug" and later made another attempt during which she substituted ladybug for bug.

Talk created an exploratory space that allowed Becky to reorganize the information given to her in order for her to make another prediction that would make sense within the sentence. In this example, Becky made a decision to forgo the lettersound relationships in the word angel to confirm a prediction based on meaning, syntax, and pictures. It seems that, in this example, the talk allowed Becky to weigh her choices when she came across a difficult area. By weighing her choices, Becky could make an informed decision on how to modify her oral reading.

In another example, Becky did not want to ignore the letter-sound information and used talk to explore it. In this case, Becky was reading the sentence "So the hen danced a jig and sat on a pig" (Lewison, 1992, p. 10-11).

"The chicken. Chick. Hen," Becky read. "What does this word say?" pointing to the word hen.

"What do you think it says?" I asked.

"Hen," Becky replied.

"Okay."

"A ...," Becky started to read.

" $/ \mathrm{d} / \ldots / \mathrm{g} / \ldots / \mathrm{d} / \ldots / \mathrm{i} / \ldots / \mathrm{g} /{ }^{\prime}$ Becky tried to sound out the word $j i g$.

"Dig," Becky read. "Does that make sense?"

"What do you think?"

"No. It doesn't," Becky replied. "So the hen ...," Becky started to read.

"I don't know," Becky said.

"What could you do?" I asked.

"Hen ...," Becky started to read, "dancing on a ..."

“/j/ /i//g/," Becky made a second attempt at the word jig.

"Jig," Becky read.

"That makes sense," Becky confirmed.

"And sat on a pig," Becky read.

Becky's final produced sentence read, "So the hen dancing on a jig and sat on a pig." In the opening of the dialogue, Becky wanted to make sure that she read the word hen correctly. When I asked her, "What do you think it says," Becky confirmed that the 
word was hen and then started to sound out the word jig. When she read dig instead of jig, Becky again wanted confirmation, asking, "Does that make sense?" Becky was not necessarily talking about the meaning of the sentence. Instead, she was wanted confirmation that the word she said was the actual word on the page, probably because Becky was not completely sure that she had produced the correct sounds for the letters. Becky disconfirmed her prediction, and by reading "Dancing on a . ..," she very likely collected some contextual information. This information, with Becky's second attempt at the letter sounds in jig, allowed her to produce the expected response. When Becky said, "That makes sense," she was satisfied with her attempt at the word. Although Becky's final sentence was not grammatically acceptable, her exploration of letter-sound relationships in written language led her to the target word.

Unlike her behavior in the previous example, Becky did not want to forgo the orthographic and phonemic information. Instead, the above episode illustrates the amount of work in which Becky engaged to reach immediate goals. Having her oral reading make sense and producing target words were her two main goals. While she was somewhat overly focused on the letter-sound information in the word jig, the content of the talk exemplifies how Becky constantly resampled letter-sound, semantic, and some syntactic information in the text. The function of each of Becky's shifts in an episode allowed her to collect more information that would provide her with the opportunity to problem-solve through areas that were giving her difficulty.

\section{The Insights Gained from Analyzing Talk}

The insights gained from analyzing talk that accompanied the oral reading events highlight how making sense was Becky's main focus. During the initial interview, I asked Becky what she does when she comes to a word that she does not know when she reads, to which she responded "sound it out" or "clap it out." Becky's response to the question reflects common instructional discourses associated with remedial reading programs. The content of Becky's talk, however, illustrates that she did more than focus on "sounding out" the words while reading. While Becky was able to articulate the sounding-out strategy in her interview, analyzing the talk that was embedded in the oral reading formats suggested another important strategy: monitoring one's reading for meaning. Exploring written language features, which occurred $27.5 \%$ of the time, appeared in conjunction with acknowledging that her reading should make sense, which she did a total of $60 \%$ of the time, by either confirming or disconfirming her oral reading attempts.

In other words, Becky worked at the act of comprehending as she read (Arya, Wilson, \& Martens, 2009; Goodman, 1996). Goodman (1996) differentiated between comprehending and comprehension. While he argued that comprehension is the product of reading or the overall sense made from the reading, comprehending occurs during the reading when the reader attempts to make sense of written texts. Becky's attempts at making sense of stories - her drive for actively comprehending what she was readingwas realized through the mode of talk.

For instance, in the following example, Becky was reading the sentence "My big brother was sick today" (Smith, 1996, p. 2). 
"My big brother," Becky read. "That makes sense," she commented.

"My big brother said," Becky reread.

In this short episode, after Becky read "my big brother," she confirmed her prediction by saying "that makes sense." Consequently, when she went back to reading the sentence, she read it as "my big brother said" instead of "my big brother was."

Here, Becky attempted the sentence "So the duck quacked again and sat on a hen" (Lewison, 1992, p. 6-7).

"So the duck took," Becky read. "/a/.../a/.../g/.../g/...," Becky tried to sound out the word again.

"Blank. I don't know," Becky said.

"So the duck made," Beck continued to read.

"No. It's not," Becky commented. "And sat on the hen," she read. "I don't know those two words," Becky said, pointing to quacked and again.

In this example, Becky had trouble with the word again. The first time she came across the word, she wanted to sound it out but could not identify enough of the sounds that would allow her to make a logical predication. Consequently, she substituted a word that did not look like again but made sense within the first part of the sentence. Becky went on to disconfirm her response by saying, "No. It's not [made]."

The above episodes illustrate how reading is not only a constructive process but also a decision-making process. Through talking, Becky could move out of the act of reading to propose questions and to ask for advice from a more experienced member. As the various examples suggest, each time Becky engaged in talk, she gathered some information and began to construct and at times co-construct solutions to her problems. More importantly, through these engagements, Becky sorted out what would make sense and what appeared to be right in terms of the problems she encountered.

At the same time, as Becky collected information, she needed to weigh the information and make decisions on its importance to her immediate problem. Needless to say, there were times when sounding out did not provide the solution that Becky wanted. Instead of forcing the strategy, Becky came up with other solutions to her problems, such as putting in a word that made sense or using the picture to support her reading of the words. Having the agency to select from other strategies, Becky could demonstrate her strengths as a reader.

This point counters the ways in which Becky's mom and the school viewed Becky as a reader. During the initial interview, Nancy described Becky as follows:

Becky is not a confident reader or a good reader. She barely reads. She has a learning disability. I don't know exactly what is Becky's problem in reading or how she is being helped in school. I know that she is working on a K-1 level. She seems to have lost some skills (in her reading). She has become less fluent and reads very choppy since she focuses on stretching out the words. I would like for her to look at her homework and read the directions and see what it's saying. But she doesn't want to try. 
Contrarily, the content of the think alouds illustrates how much Becky was trying when she read. Analyzing Becky's oral reading performance or documenting how she talks about her reading strategies through interviews alone did not provide insights into the work and decisions that were involved in reading. Instead, listening to, questioning, and probing into Becky's talk that accompanied the oral readings provided more insights into what Becky was thinking and doing as she was reading.

Taking Becky's talk into account offers a window into her thinking processes while comprehending written texts. On the one hand, by engaging in talk, Becky's reading did sound choppy, as the accompanying talk disrupted her reading flow. On the other hand, the talk appeared to serve valuable functions for her and, as seen here, demonstrated her potential in using more than one reading strategy. Furthermore, Becky used the content of her talk in her oral reading $80 \%$ of the time, which again means that she did more than focus on the words. Instead, she attended to her thinking and this was illustrated in her talk, which demonstrated more complex understandings of reading by confirming and disconfirming her predictions.

\section{Reading Partners as Strategic Partners}

By listening to and engaging in talk, Becky, Nancy, and I created a space for all of us to investigate and understand Becky's oral reading behaviors. As I noted earlier, Nancy exhibited frustration with Becky's reading abilities on many different levels. On the one hand, she felt that Becky did not try hard enough and on the other hand, she felt helpless when it came to helping Becky. When I asked Nancy how she helps Becky, she replied, "I don't know how to help. I don't know anything. I don't know what to do. I cannot relate. She doesn't have any strengths. I just want her to be a normal child." Nancy's frustration with Becky's reading abilities started to frame a negative identity of her child academically. At the same time, Nancy also expressed frustration when working with Becky. In one particular session, Nancy said, "It's frustrating watching her get the word out. I notice she says the word right and then says that can't be right and goes back to it and gets it wrong." Nancy felt that the only way to help Becky was to give her the word when she was having difficulty.

Talk through the form of questioning was a particularly important means of generating an exploratory space for Becky and me to think aloud on a social level. In analyzing the data, it became clear that the major technique that I used, which Nancy observed, was the elicitation technique (see Table 6), particularly questioning, as a means of guiding Becky's participation and in continuing the exploration process when Becky was having difficulty with her reading. Nancy acknowledged the use of this technique at the closing interview when she said, "The one thing that I liked was that you showed me how to help her. I would sit there and say 'sound it out' and 'what does that word say'. Now I know that I can use other strategies." Following up, I inquired into what other strategies Nancy used with Becky to which Nancy replied, "I can ask her questions instead of giving her the answer. I realized that miscues are okay if they make sense and she can keep on going (in her reading). I try to get her to think about the story."

In one session, Nancy, Becky, and I reflected on the following dialogue: 
"Ice cream cone," Becky finished reading the sentence "Sometimes it looked like an ice cream cone" (Shaw, 1947, p. 12).

"What does this say?" Becky asked pointing to the word cone.

"What do you think it says?" I asked.

"Cone," Becky replied.

"Does that make sense?" I questioned.

"Ice cream cone," Becky said. "Yes."

"It was an ice cream cone," Becky continued reading.

In this example, Becky asked, "What does this say?" Instead of giving her the answer, I replied with another question because I did not want to shift the talk during my turn and I wanted Becky to provide more information about the subject on which she is focusing (e.g., the picture, the first letter, or some repetition in the book). During our reflection time, the following dialogue emerged between Nancy and me,

"Even when she knows the word, she doesn't think it is right," Nancy said about Becky's desire to ask for the word.

"In some ways it shows that she's monitoring herself. She wants confirmation from someone else when she can do it herself. The idea is to allow Becky to be more independent in self-monitoring herself," I replied.

"And I can do that by not giving her the answer."

Nancy noticed that refraining from answering Becky's questions did not necessarily impede Becky's reading. Instead, questioning assisted in building analytical skills that helped Becky in making certain decisions when reading. Whether or not Nancy realized it, she expressed concern in the analytical area when she said, "I noticed she says the word right and then says that can't be right and goes back to it and gets it wrong." In other words, Becky needed the freedom to make decisions, which is something that cannot be done when she is always given the correct answer to a question she posed.

Nancy learned that being an informed listener is not necessarily listening for questions to answer. Instead, posing further questions creates and encourages further risk-taking when reading. Being a strategic partner means understanding how and when to respond to a reader, but to become a strategic partner, one needs to become an informed listener who knows how to listen effectively. Part of the reason that Nancy volunteered for the study was that she felt "in the dark" on how to help Becky with reading. Observing my interactions with Becky shed light on the complexity of the reading process as a meaning-construction process, which in turn helped Nancy to develop more effective reading interactions with her daughter.

\section{Concluding Thoughts}

Becky and Nancy's case study provides insights into the dynamic, interpersonal nature of parents working with their children, as well as implications for educators supporting students and parents around reading. On a social level, as a mother-daughter dyad, Becky and Nancy's experiences offer a glimpse into the emotional strain that 
parents can feel when interacting with their struggling readers when parents feel that they do not know how to help them. It cannot be assumed that parents know how to react productively to their children when reading with them. Nancy's frustration with Becky was, in part, due to Nancy's perceived lack of knowledge about how to help Becky with reading. Nancy stated two main strategies that she would use: sounding-out and giving Becky the word. While these are not necessarily "bad" strategies, using them repeatedly over time is limiting and does not provide a context for dialogue in the joint construction of knowledge. At the same time, Becky said that when she has difficulty, she sounds or claps out the word. By participating in the study, both Nancy and Becky started to understand that how they talk about their reading does not necessarily reflect what they do when they read. Nancy received assistance in making sense of Becky's reading behaviors and how to respond productively to them.

Providing an interactive structure where teachers, parents, and children can jointly become problem-posers and problem-solvers in educational contexts encourages educators to rethink the nature and structure of home-school partnerships (Endrizzi, 2008; Kabuto, 2009). Endrizzi $(2004 ; 2008)$ argues that there are three paradigms of homeschool partnerships: avoidance, dependency, and mutualism. Avoidance and dependency frameworks, as dominant orientations towards parental involvement in schools, view educators as playing the authoritative and guiding role in student learning. Parent and school interactions are left to formal meeting occasions, such as Back-to-School night, parent-teacher conferences, or parent volunteering, where teachers impart knowledge to parents and parents support the curricular activities at school and at home. As Becky and Nancy's case study illustrates, Nancy read with Becky and supported her reading in the home. Yet, when questions and tensions arose, she did not have anywhere to take them. Within traditional views of home-school partnerships, there is little room for constructive, exploratory dialogue aimed at understanding reading processes with the goal of supporting parents in helping their children.

Taking the view of mutualism, however, creates a joint venture around mutual respect as parents' voices, questions, and stories are heard (Endrizzi, 2004). Endrizzi (2004) writes, "Home-school partnerships, when seen as occasions for teachers and families to 'learn deliberately,' become a vehicle for transforming relationships"' (p. 325). Within this framework, there are shared responsibilities between educators, parents, and children in learning processes. More importantly, it is within this orientation where educators can assist parents in becoming informed listeners and strategic reading partners with their children.

While the study presented in this article aimed at taking a mutualistic orientation towards parental involvement, there are certain realities within educational settings that can provide barriers in implementing this type of parental interaction. For instance, I, along with others (e.g. Endrizzi, 2004), found that the demands of meeting state and local curricular mandates, time, and parent and child schedules can impede on how and when educators engage parents in interactive reading sessions. Finding ways to modify and adopt common parental involvement activities to focus on mutualism between educators and parents needs to be at the forefront in order to create effective home-school partnerships. More importantly, this movement needs to be a school-wide aspiration with the support of interdisciplinary teams of administrators, counselors, specialists, and staff. 
With school-wide support, schools can charter programs that address not just the whole child, but also the whole family.

Under such a mission, schools can provide a place and time for parents to raise focused questions around reading processes, reflect on their own reading, and inquire about their children's reading behaviors. In addition, parents can work directly with teachers and specialists in ways that help parents become strategic reading partners who know how to establish effective reading interactions where problem-posing and problemsolving are at the core. Under such a vision, the aim is not necessarily accuracy when reading, but instead, what makes sense. Parents like Nancy should not be left to feel "in the dark," especially when they want to work in the best interests of their children.

Consequently, Nancy and Becky's case study suggests that in order to help children improve their reading, reading partners need to know how to talk and respond to readers, particularly struggling readers like Becky, whose self-verbalizations might serve to slow down the reading in order for them to engage in reading processes effectively. While not every student will engage in talk when reading aloud, Becky did and her selfverbalizations demonstrated many strengths and understandings that would not be ascertained by common reading assessments, such as a miscue analysis or running record, neither of which employ techniques for assessing self-verbalizing talk that accompanies oral readings. As Crain-Thoreson, Lippman, and McClendon-Magnuson (1997) and Kucan and Beck (1997) note, talk can provide a valuable source of information about reading processes that other assessments cannot provide. In fact, the talk that emerged out of the reading events engaged all of the participants because it served as a tool for the process of thinking - intrapersonally and interpersonally - and the joint exploration of knowledge (Mercer, 2000; Vygotsky, 1986). Becky was able to discuss and problemsolve through reading strategies that allowed her to enter into and engage in her oral reading while monitoring her comprehension. Nancy and I were better able to understand Becky's reading behaviors in order to generate techniques for effectively interacting with Becky around reading.

Nancy and Becky's case study illustrates the importance of how reading partners, including teachers and parents, can co-construct the reading format through their use of talk. Any partner who reads with children is not isolated or invisible in the interactions, and as a result, need to be conscious of the interactions taking place. Instead of being a passive partner who is physically present and listens, participants can become strategic partners who construct the reading event into an authentic time for making sense of reading and solving problems in order to support children's literacy development.

\section{References}

Agar, M. (1996). The professional stranger: An informal introduction to ethnography. New York, NY: Academic Press.

Arya, P., Wilson, G. P., \& Martens, P. (2009). "We-e-el-1" or "We'll": Children negotiating orthographic features of A Letter to Amy. Reading Teacher, 63(3), 224-233. 
Barnes, D. (1993). Supporting exploratory talk for learning. In K. M. Pierce \& C. J. Gilles (Eds.), Cycles of meaning: Exploring the potential of talk in learning communities (pp. 17-34). Portsmouth, NH: Heinemann.

Crain-Thoreson, C., Lippman, M., \& McClendon-Magnuson, D. (1997). Windows on comprehension: Reading comprehension processes as revealed by two think-aloud procedures. Journal of Educational Psychology, 89(4), 579-591.

Duke, N. K., \& Pearson, P. (2002). Effective practices for developing reading comprehension. In A. E. Farstrup \& S. Samuels (Eds.), What research has to say about reading instruction (pp. 205-242). Newark, DE: International Reading Association.

Endrizzi, C.K. (2004). "We've got to talk": Redefining our work with families. Language Arts, 81(4), 323-333.

Endrizzi, C.K. (2008). Becoming teammates: Teachers and families as literacy partners. Urbana, IL: National Council of Teachers of English.

Goodman, K. (1996). On reading. Portsmouth, NH: Heinemann.

Goodman, Y. \& Marek, A. (1996). Retrospective miscue analysis: Revaluing readers and reading. Katonoh, NJ: Richard Owen Publishers.

Goodman, Y., Watson, D., \& Burke, C. L. (2005). Reading miscue inventory: From evaluation to instruction (2nd ed.). New York, NY: Richard C. Owen.

Israel, S., \& Massey, D. (2005). Metacognitive think-alouds: Using a gradual release model with middle school students. In S. Israel, C. C. Block, K. Bauserman, \& K. Kinnucan-Welsch (Eds.). Metacognition in literacy learning: Theory, assessment, instruction, and professional development (pp. 183-198). Mahwah, NJ: Lawrence Erlbaum.

Kabuto, B. (2009). Parents and children reading together: The possibilities of family RMA. The Reading Teacher, 63(3), 212-223.

Kucan, L., \& Beck, I. (1997). Thinking aloud and reading comprehension research: Inquiry, instruction, and social interaction. Review of Educational Research, 67(3), 271-299.

Kymes, A. (2005). Teaching online comprehension strategies using think alouds. Journal of Adolescent and Adult Literacy, 48(6), 492-500.

Lave, J., \& Wenger, E. (1991). Situated learning: Legitimate peripheral participation. New York, NY: Cambridge University Press.

Leslie, L., \& Caldwell, J. (2006). Qualitative reading inventory-4. New York, NY: Pearson.

Lewison, W. C. (1992). Buzz said the bee. New York, NY: Scholastic.

Mercer, N. (2000). Words and minds: How we use language to think together. London, UK: Routledge.

Oster, L. (2001). Using the think-aloud for reading instruction. Reading Teacher, 55(1), 64-69.

Pantaleo, S. (2007). Interthinking: Young children using language to think collectively during interactive read-alouds. Early Childhood Education Journal, 34(6), 439447. 
Rogers, R. (2004). A critical discourse analysis of literate identities across contexts: Alignment and conflict. In R. Rogers (Ed.), Critical discourse analysis in education (pp. 51-78). New York, NY: Routledge.

Shaw, C. (1947). It looked like spilt milk. New York: Harper Collins.

Staslowoski, M. \& Creaghead, N. (2001). Reading comprehension: A language intervention target from early childhood through adolescence. Seminars in Speech and Language, 22(3), 185-196.

Smith, R. J. (1996). Going to school. Bothell, WA: Wright Group.

Thomas, D. (2003). A general inductive approach for qualitative data analysis. Retrieved from http://www.fmhs.auckland.ac.nz/soph/centres/hrmas/_docs/Inductive2003.pdf.

Vygotsky, L. (1986). Thought and language. Cambridge, MA: MIT Press.

Wolf, M. K., Crosson, A., \& Resnick, L. (2004). Classroom talk for rigorous reading comprehension instruction. Reading Psychology, 26(1), 27-53.

\section{Author Biography}

Bobbie Kabuto is an Assistant Professor of Literacy Education at Queens College, City University of New York. She holds a PhD in Language, Reading and Cognition and her research interests include reading and writing in multiple languages, family literacy and socially constructed identities. 